\title{
Open
}

\section{The new environmentalism of everyday life: Sustainability, material flows and movements}

\author{
David Schlosberg ${ }^{\mathrm{a}, *}$ and Romand Coles ${ }^{\mathrm{b}}$ \\ ${ }^{a}$ University of Sydney, Sydney NSW 2006, Australia. \\ ${ }^{\mathrm{b}}$ Australian Catholic University, North Sydney NSW 2060, Australia. \\ *Corresponding author.
}

\begin{abstract}
This article analyzes recent developments in environmental activism, in particular movements focused on reconfiguring material flows. The desire for sustainability has spawned an interest in changing the material relationship between humans, other beings, and the non-human realm. No longer willing to take part in unsustainable practices and institutions, and not satisfied with purely individualistic and consumer responses, a growing focus of environmental movement groups is on restructuring everyday practices of circulation, for example, on sustainable food, renewable energy, and making. The shift to a more sustainable materialism is examined using three frameworks: a move beyond an individualist and value-focused notion of post-materialism, into a focus on collective practices and institutions for the provision of the basic needs of everyday life; Foucault's conceptions of governmentality and biopolitics, which articulate modes of power around the circulation of things, information, and individuals; and a new ethos around vibrant and sustainable materialism with an explicit recognition of human immersion in non-human natural systems. These frames allow us to see and interpret common themes across numerous, seemingly disparate initiatives focused on replacing unsustainable practices and forging alternative flows.
\end{abstract}

Contemporary Political Theory (2016) 15, 160-181. doi:10.1057/cpt.2015.34;

published online 30 June 2015

Keywords: Environmentalism; social movements; new materialism; governmentality; post-materialism; sustainability

The online version of this article is available Open Access

In this article, we examine the genesis and impact of a number of new social movements in several industrialized countries - movements that represent new growths of radical democracy, but in ways that illustrate innovative collective responses to, and critiques of, a range of problems with the production, supply, and circulation of everyday material needs. From fast-growing parts of the environmental 
and environmental justice movements, to community responses to a post-carbon necessity and a climate-challenged world, to an embrace of new domesticity in crafting, a range of movements offer new modes of organization, forms of resistance, and prefigurative models of democratic living, all immersed in re-formed relations with each other and the natural world.

We posit three key analytical frames that help us think about these movements theoretically, politically and environmentally. First, beyond an individualistic, value or interest-based post-materialism, we see such movements as representative of a new and sustainable materialism - one that is embodied by and embedded in collective institutions of material flows. Second, we examine these movements as a form of resistance to what Foucault called circulatory power. Beyond resistance to various problematic practices of industrialized food, energy and production of goods, we argue, these movements are creating and participating in alternative circulations of power and material nature in new collectivities. They are examples of reconstruction, in addition to resistance. Third, and relatedly, these movements read a maladaptation, or a misaligned relationship, between humans and the non-human world as a key challenge, and rethink and redesign the practices and processes that supply us with the basic needs of our material lives in a way that acknowledges the human immersion in and deeply co-constitutive relationship with - the flows of the non-human realm.

Ultimately, our argument is that there is a way to theorize, understand and link a wide variety of new movements and practices. These groups are themselves responding to, and tying together, concerns about and resistance to the disconnect and capture of the political process, the dominant and encompassing circulations of power, and the alienation and resultant destruction of the non-human realm. Previous theoretical reflections have focused on single values or concerns - sufficiency (Princen, 2005), sacrifice (Maniates and Meyer, 2010), or justice (Schlosberg, 2007). While each of these frames remains absolutely key, we see promise in a particular reading of new materialism - a concern with power, politics, and sustainability represented in the materials and flows through both human and non-human communities. These movements represent a new politics of sustainable materialism, an environmentalism of everyday life.

Our intent is not to universalize or to discount the specific motivations of a variety of creative movements, but to theorize the connective tissue that seems to hold these movements together to form a pluralistic mosaic of this new form of environmental action. We readily acknowledge that our focus is a set of movements in industrialized nations - and primarily English-speaking contexts at that. Critiques of theoretical positions, and numerous examples of these movements, come out of the south and inform our approach (for example, Guha and Martinez-Alier, 1997; Esteva and Prakash, 1998; and Shiva, 2008), but the cases for this initial study do not. Our goal is simply to develop a new and unique theoretical approach for understanding a range of these movements, to draw political and strategic links between seemingly disparate group interests and foci, and to provide a framework for examining additional movements and contexts. 
We start with a general overview of the types of movements to which we refer. While this is not meant as a set of thorough case studies, it is important to lay out what we see as new movements focused on everyday life before the discussion of the various frameworks of our analysis. We then close with some potential critiques and concerns and our initial responses to those.

\section{Food, Energy, Making - New Materialist Movements}

A variety of movements can be seen in the sustainable materialist frame we discuss. Recent food movements serve as one example here - the growth of farmers' markets, community supported agriculture, food policy councils and more. Between 1994 and 2012, the number of farmers' markets in the United States rose from 1755 to 7864 , with a 9.6 per cent annual growth rate in the last year alone (USDA, 2013). These markets serve millions of people in the United States, many of whom use them as their primary source of fresh fruits and vegetables. A growing network of food policy councils (FPC) are another case; FPCs, which consist of diverse constituencies in states and cities, are grassroots democratic networks that, on the one hand, resist junk food in schools, food insecurity, food deserts in urban areas, unsustainable agriculture, and, on the other hand, work to construct food systems which are good for farmers, the health of consumers, and the environment (Winne, 2011; Agyeman, 2013). Since the first FPC formed in 1986, 100 have formed in states and cities across the United States (Winne, 2011, pp. 158-159). There has similarly been a rapid growth of Community Supported Agriculture farms (CSAs), which create an intimate and reliable relationship and partnership between farmers and consumers; CSAs now number somewhere between 1800 and 2300 in the United States. And there are increasing numbers of food-based examples of the trend toward collaborative consumption - sophisticated sharing networks for produce. These and other local food-focused initiatives, organized by grassroots networks, have helped to increase the number of farms in the United States reversing a long twentieth century trend of decline. This growth is led by small farms and urban farms - many of whose owners are young people, recent immigrants, and/or women (Gottlieb and Joshi, 2010).

These groups have often developed out of previous social justice and environmental concerns and struggles. Detroit, for example, has one of the most promising alternative urban agriculture food justice movements in the United States. As a result of an evolving grassroots organizing tradition indebted to histories of radical union, civil rights, black power and environmental justice movements, Detroiters have been initiating a growing array of community and environmental initiatives that are attracting attention from around the world. Among these, the non-profit Detroit Agriculture Network counts nearly 900 urban gardens and farms within the city. This puts Detroit at the forefront of a vibrant national movement to grow more food locally and lessen the community's dependence on industrialized agriculture and its 
associated problems (Whitford, 2009; Boggs, 2012). While some early environmental justice advocates eschewed the whole idea of food self-sufficiency (as it reminded them of a sharecropping past), concerns with food access, economic development, health, and community revitalization, cultural preservation and connection to land and environment have helped anchor and drive these new movement organizations. Similar concerns with social justice and community functioning and development are manifested in food justice movements in many cities.

Another illustration of this concern with the flow of what and how communities eat is the 'slow food' movement, started in Italy and active across Europe, the United States and Australia. At the micro-level of gathering to eat, millions are beginning to circulate away from the impoverished homogeneity of industrial food systems. Resisting the inattentive eating, careless haste, and ecological oblivion of fast food (agri)culture, multitudes are seeking slower modes of producing, distributing, preparing and eating food in ways that seek to wed pleasure to awareness and responsibility, study and knowledge, and to offer opportunities for development even to poor and depressed regions through a new model of agriculture' favoring biodiversity across several continents (Petrini, 2004, pp. xvii-xviii). Regardless of the critiques of 'slow food' being overwhelmingly rich and western, or inattentive to the political nature of global versus local food (Honig in Browning, 2008, p. 439), this is not only a developed-world focus; in addition to the environmental justice/ community of color focus in the United States, Esteva and Prakash (1998) have discussed resonant initiatives in Latin America, and Shiva (2007) has long documented such movements in India. The point is not simply that food movements are growing, but that they are being articulated as alternative structures of community organization and material flows, simultaneously, if in different ways, in many communities across the globe (Petrini, 2010).

Whether they are based in a response to hunger, food insecurity and food deserts in inner cities, or in a more direct response to the carbon outputs of industrialized agriculture, or in response to the loss of traditional foods and practices, these movements share many of the same goals - challenging power and creating new collective institutions and food systems that embody sustainable material relationships between human communities and the natural world that supplies our needs. Combined, these movements represent the development of a new model of circulation around agriculture and food.

Likewise, energy movements - from the increasing number of community energy initiatives in the United Kingdom (Walker et al., 2010; Bomberg and McEwen, 2012), to the growing network of transition towns and initiatives across Europe (Barry, 2012), to a 'just transition' beyond coal and nuclear and to wind and solar on the Navajo reservation - are expanding the way that energy is produced and distributed, and how communities will design themselves for a post-carbon future. Again, there are numerous motivations here, from sustainability, to the survivalism of some peak-oil transition advocates, to those who want to, literally, take power out 
of the hands of the big producers and polluters. Wind and solar power have often been touted as integral to what Lovins (1979) famously coined the 'soft energy path'. Because wind and solar are widely dispersed they have often been taken to be particularly amenable to - and even richly suggestive of - highly decentralized production and distribution, in ways that could release contemporary economies from the powerful circulations of fossil fuels. As such, alternative energy practices illustrate sustainable materialist possibilities akin to those emerging in agriculture. Shared energy generation is an aspect of this shift, but the limited literature on collaborative consumption (Botsman and Rogers, 2010) focuses solely on business potential, rather than movement meaning. In contrast, the Zapatista 'do it yourself' FARMA Collective, the Yansa Group's effort to link energy and economic autonomy, and the growing number of community energy cooperatives suggest that movements themselves are intentionally linking new flows of energy, finance, technology and political communities to resist and create alternatives to the mega-circulations of the carbon industry (Abramsky, 2010; Walker et al., 2010).

Another aspect of the new sustainable materialist focus has come together around alternatives in crafting and making, a 'new domesticity' that includes canning, sewing, mending, trashion and upcycling. Rather than just protesting sweatshops and working conditions, the increasing disposability of fashion, the alienation of many tech products - and their problematic relationship with industrial global capitalist power, consumer disempowerment, and various social and environmental problems - more community groups are proliferating around crafting and making. In these movements, the growing idea is the recognition of, and immersion in, the material relationships we have with the resources we use, and the transformation of means of production that have been both alienating and unsustainable. This aspect of the new sustainable materialism is quite widespread and growing in developed economies, with numerous self-defined activist groups embracing various aspects of crafting and making explicitly for environmental, economic and political reasons.

Becoming or supporting crafters using local labor and sustainable materials, or bringing the handmade back into everyday life, are simultaneously acts of individual resistance and institutional reconstruction (see, for example, Payne, 2011; Anderson, 2012; Matchar, 2013). 'This was initially about being frugal and concerned with what I put in my body ... [b]ut it became about the politics' (Payne quoted in Matchar, 2011). While some critics see the new domesticity as a move against feminist advances, and their limited mention of 'green' or 'environmental motivations may illustrate a continued break between feminist and eco-movements' (MacGregor, 2009), these practices embody a move to reclaim the processes of material life and the flows of capital, materials and power.

In part, the goal is to reclaim the value of knowing and doing, and of lost domestic arts. Based in part in post-feminist and post-punk DIY movements and a new generation of post-feminist magazines like Bust and crafter websites like Etsy, this growing set of movements has helped to reawaken interest in knitting, making 
clothes, and skills like sewing and darning in a younger and more radical audience. The domestic focus on re-engaging material relationships in the provision of everyday life is complemented by the evolution of a movement of open source programmers, tech modders, and makers focused on DIY technologies and communities - illustrated, for example, at Maker Faires and Make magazine. Here, the focus is on the alienation of technology, and yet it shares the new domesticity's interest in unplugging from the mega-circulations of global capitalism, and the importance of creating alternative flows that keep materials and making at the personal and community level.

In each of these areas, the development of community movements and institutions - beyond solely individualized action - is purposeful and pointed. There are many ways in which we are encouraged to put values into practice individually - doing 50 things to save the planet, or buying LED lightbulbs and organic produce at Walmart. But even more engaged individual actions, such as buying food at farmers' markets, putting up solar panels, or upcycling clothing, are not seen to address, or impact, larger problematic social and material practices and flows. Individual action may take some of our everyday life out of such flows, and so assuage our values. But such isolated statements are simply not seen by movement participants as enough to interrupt the flows of debilitating and anti-environmental industrialized practices.

In response, many individuals and movements have moved to address their concerns with more innovative, collective and reconstructive responses to the unsustainable institutions and practices in which their lives are immersed. So rather than simply show an interest in better-quality food, or post-carbon energy generation, these citizens and community groups are developing, participating in, and enjoying the products of new food and energy systems. The institutionalization of larger collective responses - to what are seen as errant flows of materials - is key.

Participants in these movements and practices are often keenly self-aware of their own unique political motivations, strategies and impacts, and the movements are clearly growing in numbers and scope. Academically, however, current analytic frameworks for understanding environmental movements do not adequately address this wide variety of interlinked innovations. While there are key studies of new food movements (Gottlieb and Joshi, 2010; Alcon and Agyeman, 2011), they stay focused on a justice-based framework for understanding these movements, while we see them as exemplifying a larger sustainable materialist concern as well. Much work on energy descent and transition towns confines itself to offering either technical instruction or uncritical praise (Hopkins, 2008, 2011). As for crafting and making, most of the discussion has been based on suspicion from the feminist community that new domesticity is a step backwards to the kitchen, despite participants seeing the sense of moral purpose - 'a symbol of resistance to industrial food and its environment-defiling ways .... not just fun, but necessary and even virtuous' (Matchar, 2011, p. 1). While there is a growing literature on theorizing urban environmentalism (for example, Loftus, 2012), these works do not address the 
relationship across numerous urban movements. Hess (2009) offers an insightful study of localist movements that addresses a range of these efforts including food, energy and the localist retail and media sectors. But while Hess focuses on these movements' response to globalization and the endangerment of the local, we think the conceptions of power and sustainability in these movements require the application of additional frameworks including a new materialist approach to everyday life.

Our goal here is to build and expand on this work, and more fully engage the broad and numerous distinctive political and materialist meanings of the practices of these movements and community institutions. As sketched earlier, we see three different though clearly interrelated ways of understanding and framing these movements, and their motivations, visions, meanings and obstacles - all related to the flows of power and materials through the body and community:

1. a move from the standard notion of postmaterialist politics into a sustainable materialist focus on collective practices and institutions of provision of the basic needs of everyday life;

2. Foucault's conceptions of governmentality and biopolitics, which articulate modes of power around the circulation of things, information, and individuals; and

3. an ethos of a more explicit acknowledgment of human immersion in non-human natural systems, and a shift in the understanding of human/non-human relations.

These frames illuminate common themes across numerous, seemingly disparate initiatives.

\section{Beyond Post Materialism - To Vital and Attentive Materialisms}

We argue that these movements are better understood not as examples of a next generation of post-materialism, but rather as new and practical embodiments of a new, vital, and sustainable materialism. This challenges the basis of a long-held theory of new social movements.

In the now-classic notion of postmaterialism, environmental concerns are seen as part of a range of interests that emerge after basic needs are met. As Inglehart has long argued (for example, Inglehart, 1989, 1997; Inglehart and Welzel, 2005), the satisfaction of basic needs is followed by a shift to citizens interested in a range of post-material concerns. Those with post-material values emphasize things like quality of life, community, self-expression, and human rights rather than issues of material sustenance or security, as those latter needs are seen to have already been met in developed states. The working welfare state, in this framework, provides the level of development necessary to move into a whole range of more luxurious concerns around identity, values, and non-economic interests. Environmental concerns, then, develop into a movement only after the political system as a whole 
is ready to move on beyond battles over wages, working conditions, and the staples of survival.

Politically, Inglehart was originally interested in explaining social movements of the type that developed in the 1960s and 1970s, and the way that values were being expressed both traditionally, in standard electoral and legislative interest group pressure processes, and in grassroots political engagements such as protests, boycotts and direct action. While recent work focuses on broader comparative studies of postmaterial or post-modern values (Inglehart, 1997) and the cultural shift they collectively bring, the ongoing idea is that political change comes from individual citizens who insist (either directly or through public opinion polling) that such values be represented and addressed by interest groups and/or their representatives in democratic states. The basis of this post-materialist thesis is that there will be a fairly direct link between the shift in individual values, a larger cultural shift, and a change in the political environment, such that policies will then be reflective of these new values; this post-materialism assumes liberal pluralism.

There have been numerous critiques of the way post-materialism assumes less developed nations and peoples would have less interest in environment - for example, the literature on 'environmentalism of the poor' (Guha and MartinezAlier, 1997, along with many of Vandana Shiva's works), as well as the reality of environmental justice struggles in relation to toxic waste and myriad other issues in poor communities in the United States (Bullard, 1993; Szasz, 1994). In addition, work by Dunlap on environmental values has long illustrated their presence in many countries, cultures, and economic conditions, contradicting the tight association of environmental values with post-material conditions (for example, Dunlap and Mertig, 1997). So the idea of material preconditions for environmental values has already been problematized in theory and practice.

Our argument is that the assumptions of the post-material thesis about both politics and disembodiment are also problematic. One issue is that the predicted political flow, from changed individual or collective values to the adoption of related public policies, faces an important counter-flow, long noted by critics of liberal pluralism. Contemporary actors are laden with a set of values that are reflected neither in formal politics and policy nor in the everyday interactions with the materials of basic needs. There is, thus, an implementation deficit that has become increasingly obvious and salient. Frustration with the disconnect between political and ecological values and both the everyday and large-scale political, cultural and industrial landscape and flows in which we find ourselves, we argue, has led to a growth of new groups and movements with a different - much more embodied and applied - idea of appropriate and necessary political action.

It is more than simply an awareness of values not being implemented, or of existing practices being destructive and counter to those values. This awareness of the disconnect is tied to an understanding of our concern below, about circulatory power. Political actors in the movements we discuss understand the process of 
translating these values into policy to be: thwarted by political economies of circulatory power (including the flows between corporate power and the megastate (Wolin, 2008)); and unstable insofar as they undergo reversals that appear to be a consequence of both concerted misinformation from vested corporate interests, and poor framing and organizing on the part of environmental organizations. This type of analysis has led to an increasingly widespread rethinking of power and the place of values in contemporary society, and this rethinking is in turn beginning to engender potent disruptions. These later take the form of counter- and alter-practices, powers and flows that pose new challenges to both the current biopolitical regime achieved through political economies of megacirculation and the post-materialist theoretical frame that has had substantial purchase during the period of this regime's greatest intensification and dominance. Insofar as materiality comes to be understood in terms of flows among people, non-human beings, things, and ecosystems, as we will elaborate in our third frame, values are no longer conceived as a realm somehow added from outside to material facts. Rather they are increasingly understood as immanent to the relations and orientations among moving beings - the practices, impacts, extractions, deposits, accumulations, dynamics, flourishing, degradations and enhancements in a world of becoming (for example, Connolly, 2011). From this vantage point, the sharp distinction between materialism and values makes little sense either as an ethical or a political frame.

This is a post-postmaterialism - a politics made as an alternative to the idea of a post-materialist politics where one's values are represented in existing political practice. The movements at the center of this project are focused on replacing unsustainable practices, and forging alternative productive and sustainable flows and institutions inserting themselves into wholly new material flows that are both politically and ecologically a form of resistance. No longer willing to take part in unsustainable practices and institutions, and not satisfied with a purely individualistic consumer, organization member or electoral response, the focus is increasingly on building new collective institutions around everyday practices of material sustainability.

We are - to paraphrase a venerable tradition of thinking that is at odds with modern subjectivism and the discourse of post-materialism - far more being, or material becoming, than thinking. If this is so, then to understand much about contemporary 'values' - and to work to transform our everyday lives, economies, polities and the values with which they are intertwined - will require political interventions at the level of bodies and material practices: How and what food do we produce? What relationships do those of us who do not produce most of what we eat have with those who do, and the animals, plants, soil and water on their farms? What habits of eating do and might we have? What practices of sharing and distributing food? What micro practices and disciplines of agro-ecological pedagogy do we cultivate in our schools? How are our rural and urban landscapes intertwined? How do we exchange seeds? Similar questions of bodies and material practices are being raised in relation to energy, crafts, water, medicines, currency and more. 


\section{Power, Flows, Circulations}

Clearly related, we see these movements serving as embodied responses and counters to circulatory power. For Foucault, security and governmentality begin with the 'suppression of city walls', which started to come down in the eighteenth century in response to economic growth and increasing trade; circulation of grains, goods, and people; and problems of hygiene in the midst of overcrowding. (Foucault, 2009, p. 18). The 'problem of circulation' - of which towns were to become 'the perfect agents' - is increasingly the crucial context in the exercise of power

Yet circulation is not merely a context for the apparatus of security; rather it becomes integral to the operation of this new mode of power. Governmentality works with, insinuates itself into, juxtaposes and utilizes circulations. Security operates by infiltrating, influencing and utilizing flows of criminals, goods, grains, unemployed, illegal immigrants, disease, trade and so on, in order to achieve macro outcomes that are deemed power enhancing and thus desirable. Moreover, institutions of securitized power function not only by infiltrating, but also by producing and proliferating circulations in ways that tend to reconstruct the world and human beings in order to maximize flows that generate power.

While the increased circulation of grain in the eighteenth century is among the conditions that spur the development of governmentality, Pollan's (2007) discussion of the circulation of a global 'river of corn' illustrates the extreme form such power takes today - to which new food movements reply. The human body has a relatively limited capacity to absorb food, but the industrial food circulation complex has increasingly overcome this limit by, for example, adding high-fructose corn syrup into what we eat and drink, thereby overriding biological mechanisms which otherwise shut down hunger. Our bodies, desires and lifeworlds are being reworked daily to transform us into 'industrial eaters'. Thus three-fifths of the US population is now overweight and increasingly plagued by numerous associated diseases. Americans, Pollen argues, even have particular isotopes in their bodies that mark the flow and power of the corn-based industrialized agriculture industry in their country. 'So that's us: processed corn, walking' (2007, p. 23). Berry (2010) poignantly summarizes our situation: 'The ideal industrial food consumer would be strapped to a table with a tube running from the food factory directly into his or her stomach' (p. 146) - an image even Disney illustrated in the animated film 'Wall-E' (Stanton et al, 2008). The economic circulation of corn represents and exemplifies the embodiment and functioning of contemporary power.

In response, new food and agricultural movements are developing alternative circulations to replace problematic industrialized and power-driven practices. The point is to step outside of the industrialized circulation of power through food and its associated institutions and practices, and develop alternative flows of food - from more sustainable and small-scale farm practices, to direct-to-seller farmers markets, community-supported agriculture arrangements, Food Policy Councils, urban 
gardens and more. Our argument is that contemporary movements around food, energy, water, transport and basic needs are often consciously responding to circulatory power.

Some of the most interesting loci of alternative flows have emerged from people struggling to create new forms of life that draw upon legacies of those struggling on the undersides of power. Indeed, many parts of the environmental justice movement have long focused on the circulation and infusion of toxins into the bodies of women, children and people of color (Sze, 2006; Gabrielson, 2011), and they are attentive to the fact that these groups remain disproportionately excluded from circulations of healthy food (Alcon and Agyeman, 2011). Typical of growing numbers of initiatives across the United States, in Austin, Texas, the Sustainable Food Center has established Happy Kitchen/La Cocina Alegre, in which mostly women (many immigrants of color) share recipes, nutritional information and incorporate fresh seasonal foods into their meals. Graduates of this program often become its future teachers, thus creating alternatives to typical 'expert' flows of information, and advocating for food justice aimed at disrupting dominant flows of power (Winne, 2011). On the farming side, Women, Food, and Agriculture Network has organized the women who own almost one-half of the farmland in the United States to advance more sustainable agricultural flows (http://wfan.or/about/). Movements indebted to Chicana feminism and the United Farm Workers increasingly problematize borders and dominant circulations of food and farm workers, while embracing new flows of people, sustainable modes of agricultural production, and alternatives to the racing course of things in food processing plants (for example, Apostolidis, 2010). In all these ways, those who have been subjected to the most damaging impacts of contemporary mega-circulations are among those co-creating a politics of just and sustainable material flows.

In each of these cases, movements move beyond critique and seek to replace practices and circulations of power that have devastating consequences for human health and ecological sustainability, generate vast inequalities of power, and separate us from the co-creation and sharing of basic everyday needs. They unplug individuals and collectives from these flows of industrialized food, destructive fossil fuels, and sweat-shopped disposable fashion in order to interrupt their power. While part of the attraction is the esthetics and experience of the products themselves, the focus here is on the role both the maker and consumer play in displacing undesirable flows of power and, crucially, embodying new and more, local, productive and sustainable circulations of goods and power in wholly new institutions (see also Coles, 2012).

While there are numerous examples of movement organizations taking on specific issues, flows and circulations, we see a range of these themes come together, for example, in the transition and localist movements. Originally begun in the United Kingdom, transition towns have spread across Europe, and, to a lesser extent, the United States. The idea of the movement is to lower or eliminate dependence on 
carbon-based energy, and to re-design and re-create various practices of local production while maintaining a high quality of life. As Barry (2012, p. 27) argues, the transition town movement illustrates a 'creative adaptive management' approach to building more resilient communities. They are based on the 'basic belief that communities of people can shape the conditions (socio-ecological and social) for their own flourishing' (p. 115). Likewise, as Hess (2009) explores, the localist movement in the United States, embodied, for example, in the Business Alliance for Local Living Economies. While quite diverse and pluralist, the localist movement stands as a counter to the practices and impacts of global corporations, and offers 'ingredients in projects to build more democratic, just, and sustainable politics for the twenty-first century, or at least for mitigating what some believe to be an inevitable future of environmental and social collapse' (Hess, 2009, p. 22). Building on this, we see in these movements a response to flawed and failing everyday practices that are embedded in steady flows of contemporary power relations, and reconstructive actions that take direct responsibility for interrupting and replacing such flows and re-localizing and regionalizing much of what has been taken away from communities. The goal is not simply resilience against current flows, but a transition away from them. Radical transformations of such power will require vast networks, practices, institutions and emergent powers of counter- and alter-circulation.

These new materialist movements illustrate a growing resistance to participating in the flows of power that reproduce practices that damage ecosystems or contribute to climate change. In embodying new forms of power, and being part of more sustainable flows of food, energy, and other everyday needs, these movements simultaneously express forms of resistance and empowerment. They are a counter-governmentality, an environmental/sustainable governmentality (Hobson, 2013).

\section{Vital and Sustainable Materialism: Flows and Immersions in the Non-Human}

Our final and closely related argument is that these newly reinvigorated movements are often based in understandings that involve a changed relationship with the environment in which human needs are immersed. The desire for sustainability and environmental justice has spawned an interest in transforming the very material relationship with 'resources' and the non-human realm.

The link between political and ecological frames of the vital and sustainable materialism we are examining can be seen in recent work on new materialism. Though this literature contains numerous themes and strands of inquiry, Coole and Frost (2010) discern three 'interrelated but distinctive themes' that we think usefully define and orient what we are calling the move beyond post-materialist theory and 
practice. First, there is a shift from subjectivist paradigms which privilege human cognition and valuation, to 'an orientation that is posthumanist in the sense that it conceives of matter itself as lively or as exhibiting agency' (p. 7). This matter includes but exceeds human bodies that are themselves immersed in broad flows of biotic and physical materiality with various sorts and degrees of agency. So human agency is increasingly understood as indebtedly networked with complex and dynamic agentic systems and assemblages (see also Khan, 2009; Bennett, 2010). Second, this fact of immersion raises a host of bio- and eco-political and ethical issues - a thicket of crucial questions concerning human responsibility with and for the more than human world. Finally, Coole and Frost (2010) insist that 'new materialist scholarship testifies to a critical and non-dogmatic re-engagement with political economy, where the nature of, and relationship between, the material details of everyday life and broader geopolitical and socioeconomic structures is being explored afresh' (Coole and Frost, 2010). Overall, the frame of a new materialism emphasizes and insists 'that humans, including theorists themselves, be recognized as thoroughly immersed within materiality's productive contingencies' (Coole and Frost, 2010). Politically, we see these types of questions being raised by the movements we are examining.

This framework, as we have suggested, gives rise to a new conception and practice of sustainability attentive to quotidian flows and relationships. While some have criticized new materialism for an inattention to political action (see the critique by Washick and Wingrove, with responses by Ferguson and Bennett, 2015), these critiques often miss the broad political implications of the new materialism. These movements concerned with the flows of everyday life represent a new materialist politics. The desire for sustainability, often in response to climate change, has spawned an interest in changing the very material relationship with the non-human realm. The focus of many of these movements often explicitly embodies an important shift in theoretical and practical articulations of the human relationship to the rest of the natural world. The concern is with the very flow of food, matter, energy and water - stuff - from the natural world, through our productive processes, into and through our bodies, and back into the non-human realm. This is about the reconstruction of such relationships in more sustainable practices of growing, distributing, eating, and recycling, the material that we eat, enjoy, absorb and pass through human practices and societies. There is an interest in the circulation of human power within a context of non-human nature. Many food, energy and making movement groups recognize those flows, and attempt to reconfigure flows that currently undermine the capacities of ecosystems, bodies, and human communities, into ones that enliven, support, or minimize the negative impacts on them. New institutions are being built in ways that explicitly direct the material flows of everyday life in vitalizing, resilient and sustainable ways, with specific attention to the relationship between the provision of human needs and the environment in which those needs are met. This is not just about the implementation of a specific value or logic, such as the sufficiency response to ecological 
constraints discussed by Princen (2005). The idea of 'enough' does apply to the human relationship with nature, but also to the broader institutions and practices that simply do not take that relationship into consideration.

These are not just movements for adaptation or sustainability, but for a resilient and transformative ethico-material relationship with the natural world in which human beings and communities are immersed. These movements seek to critique and replace the devitalizing and unsustainable practices of the domination of non-human nature with practices and flows that recognize human beings as animals in embedded material relationships with ecosystems and the non-human realm. The focus is forging alternative, co-creative, productive and sustainable institutions at the local and regional level that reconstruct our everyday interactions with the rest of the natural world.

Movements around new sustainable materialist practices illustrate resistance to the idea that human development must be based in either separation from or mastery of nature. The reconstructed flows of material needs are mainly designed to pay attention to the processes, possibilities, co-flourishing and limitations of nature. Movements around new practices illustrate what many have begun to theorize about this relationship. Latour (2011), for example, has been just one of many who argue that human development has for too long been based in a separation from nature. A more re-engaged movement would see 'the process of human development as neither liberation from Nature nor as fall from it, but rather as a process of becoming ever-more attached to, and intimate with' the nonhuman (p. 17). As Whiteside (2013) argues with regard to Latour (p. 203), and as the movements we discuss embody, the point is 'making vigilance over the life-sustaining capacities of our biophysical surroundings into a matter of constant concern'.

Hess (2009) sees sustainability as an increasing focus of a variety of localist movements. We agree, but think that many of these movement groups are much more explicit about the human/non-human relationship in terms of the practices of everyday vitality and vulnerability. Sustainable materialist movements are actively trying to replace a politics of separation with one of immersion, a politics of the domination of nature with one that recognizes human beings as animals in embedded material relationships with ecosystems and the non-human realm. As Barry (2012, p. 28) explains in discussing the transition movement, the aim is to 'render explicit those forms of relations of dependence on nature and fellow humans which have been occluded, forgotten, or otherwise hidden away in modernity. These include relations (material as well as symbolic) around food, the land, and the links between production, reproduction, and consumption'.

To be clear, our argument is not that such movements provide the sole or necessarily the best - answer to the host of political, economic and ecological problems faced in contemporary life. The point is simply that a growing number of activists and organizations are reframing both the form of, and justifications for, their actions along the lines of a new sustainable materialist politics. 


\section{Criticisms, Dangers, and Challenges}

These new circulatory movements of resistance and sustainable materialism have faced a number of critiques. Many of those, we believe, are fairly minor and easily addressed. The major challenge comes not from political critiques of the strategy or approach of these movements; rather, the major issue is the resilient nature of extraordinarily strong counter-flows of power - the very ones being targeted by the movements we outline.

Of course, numerous critiques of materialist and community-based strategies come from the classic view of sovereign political power. Some disapprove of the transition town movement, for example, for what they see as its apolitical nature - that they do not necessarily involve themselves in national electoral politics to seek specific sympathetic policy changes (Read, 2008), or support other movement groups fighting specific polluters (Chatterton and Cutler, 2008). Would not serious resistance and alternatives rather require the cutting edge of leadership to be focused on nation-state policy, international regulatory regimes, massive redeployments of agricultural capital, and similar non-local targets? Surely, it is difficult to imagine profound transformations on a sufficient scale that did not involve careful consideration of such changes.

But such criticisms misread politics in two crucial ways. First, and most obviously, efforts to replace unsustainable or non-resilient material practices do not replace electoral or policy-focused politics, but supplement a distant but necessary political effort that may or may not bear fruit with local, regional and transnational efforts that put one's body in the midst of actual change and the production of counter-institutions. So with the limitations of DC-based campaigns in the United States, for example, we have seen a move into the important realm of state politics and local activism of the type we are discussing. Yet we still have national-level activism, perhaps most vividly represented by the Keystone protests and 350.org. But activists pushing fossil fuel divestment, for example, are very likely engaging in some of these localized sustainable materialist practices as well. Likewise, food movements in the United States, United Kingdom and Australia aim to build new circulations of a localist food economy, but continue to lobby and protest for changes in state, national and transnational food policy as well (Schurman and Munro, 2010). Again, one form of political engagement does not simply replace the other; new materialist political action is not a zero-sum or an either/or.

Second, in the food movement and elsewhere, many criticize the supposed apolitical elitism of some advocates - those with the income and privilege to shift away from dominant practices (as illustrated, perhaps, by Pollan, 2007). But there is also a strong justice component to food and localist movements, in groups that address racism, privilege, culture, access and power (Hess, 2009; Gottlieb and Joshi, 2010; Alkon and Agyeman, 2011; Taylor, 2013). Thus, clearly there is a strong political element to these groups (often also engaged in changing local, regional, and national policies and global regimes), though they are often outside of the normal channels of electoral politics.

What we can see in such movements is not necessarily a model liberal interest group, organizing around a value and lobbying for representation at the level or sphere 
of the classic sovereign. Instead, they serve, often intentionally, as forms and examples of prefigurative politics. The focal point is not to organize to lobby or vote for change; the point is to literally embody that change, and to illustrate alternative, more resilient, and more sustainable practices and relationships. As Maniates (2012) puts it, 'In the search for a potent politics of transformation, everyday life may not be so everyday after all' - especially insofar as it promises to transform selves, communities, transborder relationships and ethical-political imaginaries in ways that may build toward broader political and economic changes. Programs emerging within the US Department of Agriculture that support alternative food initiatives are suggestive of synergies with national level policy that could be expanded to bring an alternative politics to scale (Gottlieb and Joshi, 2010; Bonfiglio, 2012). Similarly, Sirriani's (2009) study on 'collaborative governance' identifies some promising paths for combining formal democratic politics with grassroots politics oriented around alternative flows.

Yet, clearly the most important critique of such efforts is their vulnerability to the very structures and practices of the rapidly intensifying circulatory power they seek to replace. Two potentially interactive factors are particularly salient in this regard. First, dominant modes of circulation are assimilating alternative visions and practices in ways that draw new materialist flows and desires back into mega-circulations of power. Whole Foods Market, for example, has pioneered corporate organic in ways that are often greatly at odds with the democratic flows of sustainable materialism (Pollan, 2007; though not always, see Bonfiglio, 2012). Predictably, the corporate (often semi-) organic industry has moved aggressively to colonize regulatory boards that set the standards regarding what is considered organic. They have displaced smaller independent firms, colonized seats that were designated for consumer representatives, placed corporate staff who are not farmers in the seats designated for organic farmers, filled other seats with representatives of corporations that are only partly organic - and advocated for genetically modified organisms, myriad synthetic substances, and practices that are considered anathema by most in the new materialism movement (Strom, 2012). Second, and simultaneously, some articulations of the movement for sustainable materialism present it primarily as a new 'yes' that avoids more conflict-laden aspects of change. Such articulations may tend to diminish the critical vision, energies and will to engage in agonistic political actions that are also necessary to supplant problematic and targeted circulations and institutions.

The Detroit food justice movement provides an example of contestations that are likely to emerge more frequently as the politics of sustainable materialism develops. The growing success and promise of the movement has begun to draw corporate interest and potential investment in large-scale agricultural designs for Detroit - in ways that may undermine grassroots initiatives. In the eyes of many in Detroit's grassroots urban gardens movement, the symbol of this corporate-governmentality strategy to assimilate, capitalize on and undermine community-based initiatives is Hantz Group, founded by one of the richest men in Detroit. Community leaders of urban agricultural initiatives across the city contend that Hantz Group has 
non-collaboratively formulated its designs and negotiated a substantial incentives package with the mayor behind closed doors, while the city has refused to offer comparable arrangements with community groups who have been engaged in grassroots urban agriculture for years. The result, they claim, is a potential 'land grab' that will generate wealth for a few white men, undermine the autonomy and initiatives of African Americans (82 per cent of the city's population), create gentrification on the edge of farms, and threaten the viability of the delicate social and ecological systems that are beginning to re-emerge from the bottom up. Grassroots leaders, inheriting Detroit's long histories of civil rights, black power, and union struggles, have organized strong opposition to the corporate model, favoring instead a vision of a community-based land commons (Carr, 2010; Gallagher, 2010, 2012a, b; Howell, 2012). Nevertheless, Hanz Group currently appears to be gaining the upper hand, acquiring large acreage at extremely low prices (Reel, 2014).

How Detroit's community-based and corporate-driven urban agriculture initiatives may develop, radically contest one another, co-exist uneasily as part of a complex polyculture, or manage to form unexpected strategic alliances is still unclear. New materialist futures will depend significantly on the capacity of grassroots organizations to interweave resistance with supple and creative power in relation to a corporate-municipal complex that is likely to pose great challenges to the radical possibilities of new materialist movements in the city. Those in new materialist movements who are insufficiently attentive to power and allergic to contestation may be ill-prepared for challenges that will almost certainly emerge. The key question is whether these movements can resist these challenges, scale up, and pose an authentic challenge to current flows of power and goods.

Similar sorts of conflict are emerging in other sectors, such as energy production. From Denmark to Mexico, examples of collusion among large foreign corporate wind energy producers, industrial energy consumers, and government have greatly restricted community-based and cooperatively generated wind development, and supported designs more conducive to the concentrated mega-circulations of capital, energy, and finance. In response, communities are engaging in resistance movements and seeking alternatives (Kruse and Maegaard, 2010; Maegaard, 2010; Oceransky, 2010).

Contestations are underway between the logics of mega-circulation and those of sustainable materialism, and they appear to reiterate longstanding struggles between logics of enclosure and those of the commons. Yet there may be opportunities for new strategically supple forms of politics that might shift to and fro between inventive modes of collaboration and contestation in ways that might enhance the power of grassroots initiatives to co-opt 'friendlier' elements of the mega-circulatory apparatus in order to further catalyze decentered flows. In this context, new materialist movements may learn new political arts of working creatively with dynamic footing among mixed flows, modes and actors with different interests and visions, while simultaneously cultivating capacities to discern, contest, and overcome assimilative challenges posed by powerful and shifting crosscurrents (Coles, Forthcoming). 


\section{Conclusions}

In this sense, these dangers do not undermine the potential of the movements we have explored. We suspect that these challenges - and opportunities - will increasingly move to the forefront of such initiatives and will become an important focus for future research that seeks to understand and advance possibilities for new and sustainable materialist movements. We see promise in the direct critiques posed by the movement values, strategies and structures, but much more work needs to be done to understand how, or if, such movements both continue within the normative frameworks we suggest here, and whether those approaches can successfully replace the powerful practices and flows being challenged.

As noted earlier, the argument here is not that these movements represent the singular or even majoritarian evolution of new environmental movements. They are, however, representative of a crucial and growing disposition and practice. If there is little reason to believe that most people have the full-blown desire, vision or power to directly disable the main trunks and channels of circulatory governmentality, what we are seeing is, perhaps, the gradual reconstitution of a number of individuals, communities and practices of (agri)cultural production, fabrication, distribution and consumption at sites along the capillary flows of output and absorption. As Esteva puts it, "Coca Cola or Marlboro have "no real existence" or power where people ignore them; they have no more power than the power people give to them by "believing" in what they offer' (Esteva and Prakash, 1998, p. 31). Our question is about transforming that belief into everyday life. And how might people organize massive disbelief and alternative visions and practices at the capillary levels of our engagement? Exactly by replacing the existing flows with new, local, engaged systems of community production and consumption.

In food justice movements, new energy collectives, and even in many crafting producers, there is the sense that, as human societies bring on climate change and a variety of other environmental and political ills, the very construction of how we immerse ourselves in the natural world, and how we provide for our basic needs, is simply not working. The mythology of current circulations, practices, and relationships - both within human communities and across the human/non-human divide - is being increasingly challenged. Movement groups see current practices weaken the capacities of selves, human communities, and human-ecological assemblages alike and begin to question the daily participation in social and material practices that have led us to our current predicament.

Individual action - a vote, or, more likely, specific purchases - may take us momentarily out of problematic flows, and so appease our values. But such isolated statements are simply not enough to interrupt the flows of debilitating, anti-environmental and unjust industrialized practices. This is why, we argue, we see more and more citizen and community groups developing, participating in and enjoying the products of new and alternative food flows and energy systems. 
These are collective responses of movements, and the institutionalizations of community-sized alternative and sustainable flows of materials and practices of everyday life. They confront power by stepping out of existing flows of materials and capital. They confront vacuous and individualist politics by embodying alternatives rather than just supporting values, policies, or candidates. And they embrace the human immersion in the rest of the natural world, by reconfiguring the flow of food, energy, and other basic needs.

\section{Acknowledgements}

The authors thank Sam Chambers and the reviewers for CPT for incisive suggestions on an earlier version of this essay. Thanks also to John Meyer and the participants in the workshop on The Greening of Everyday Life at the Rachel Carson Center, Munich, June 2014. The author would also like to acknowledge the funding of the Australian Research Council, grant DP140103863, which made a portion of this research possible.

\section{About the Authors}

David Schlosberg is Professor of Environmental Politics in the Department of Government and International Relations at the University of Sydney, and co-Director of the Sydney Environment Institute. His work focuses primarily on environmental political thought, environmental and climate justice, and the theory and practice of environmental movements. Recent books include The Oxford Handbook of Environmental Political Theory (Oxford 2015, co-edited with Cheryl Hall, Teena Gabrielson, and John Meyer), Political Animals and Animal Politics (Palgrave 2014, co-edited with Marcel Wissenburg) and Climate-Challenged Society (Oxford 2013, co-authored with John Dryzek and Richard Norgaard).

Romand Coles is a research professor at the Institute for Social Justice at Australian Catholic University in Sydney, Australia. His work focuses on intersections among political theory, action research, ecological thought and social movements. His books included Visionary Pragmatism: Radical and Ecological Democracy (Duke University Press, forthcoming); Radical Future Pasts: Untimely Political Theory, edited with Mark Reinhardt and George Shulman (University of Kentucky Press, 2014); Christianity, Democracy and the Radical Ordinary: Conversations between a Radical Democrat and a Christian, with Stanley Hauerwas (Wipf and Stock, 2007); and Beyond Gated Politics: Reflections for the Possibility of Democracy (University of Minnesota Press, 2005). 


\section{References}

Apostolidis, P. (2010) Breaks in the Chain: What Immigrant Workers can Teach America about Democracy. Minneapolis, MN: University of Minnesota Press.

Abramsky, K. (ed.) (2010) Sparking a Worldwide Energy Revolution: Social Struggles in the Transition to a Post-Petrol World. Oakland, CA: AK Press.

Agyeman, J. (2013) Introducing Just Sustainabilities: Policy, Planning, and Practice. London: Zed Books.

Alcon, A.H. and Agyeman, J. (2011) Cultivating Food Justice: Race, Class, and Sustainability. Cambridge, MA: MIT Press.

Anderson, C. (2012) Makers: The New Industrial Revolution. New York: Crown Business.

Barry, J. (2012) The Politics of Actually Existing Unsustainability: Human Flourishing in a ClimateChanged, Carbon-Constrained World. Oxford: Oxford University Press.

Bennett, J. (2010) Vibrant matter: a political ecology of things. Raleigh, NC: Duke University Press.

Berry, W. (2010) What Are People For?, 2nd edn. Berkeley, CA: Conterpoint Press.

Boggs, G.L. (2012) The Next American Revolution: Sustainable Activism for the Twenty-First Century. Berkeley, CA: University of California Press.

Bonfiglio, O. (2012) Big government and big corporations befriend the local food movement. Energy Bulletin, 16 February. olgabonfiglio.blogspot.com/2012/02/big-government-and-big-corporations.html, accessed 17 May 2013.

Bomberg, E. and McEwen, N. (2012) Mobilizing community energy. Energy Policy 51: 435-444.

Botsman, R. and Rogers, R. (2010) What's Mine is Yours: The Rise of Collaborative Consumption. New York: HarperBusiness.

Browning, G. (2008) An interview with Bonnie Honig. Contemporary Political Theory 7(4): 434-443.

Bullard, R. (1993) Confronting Environmental Racism: Voices from the Grassroots. Boston, MA: South End Press.

Carr, A. (2010) Detroit: The business of urban agriculture. The Boggs Blog. conversationsthatyouwillneverfinish.wordpress.com/2010/08/11/detroit-the-business-of-urban-agriculture, accessed 16 May 2013.

Chatterton, P. and Cutler, A. (2008) The Rocky Road to a Real Transition: The Transition Towns Movement and What It Means for Social Change, http://www.paulchatterton.com/2009/08/17/therocky-road-to-a-real-transition-reprinted-with-new-preface/, accessed 6 June 2015.

Coles, R. (Forthcoming) Visionary Pragmatism: Radical and Ecological Democracy, Forthcoming Durham, NC: Duke University Press.

Coles, R. (2012) The promise of democratic populism in the face of contemporary power. The Good Society 21(2): 177-193.

Coole, D. and Frost, S. (eds.) (2010) New Materialisms: Ontology, Agency, and Politics. Durham, NC: Duke University Press.

Connolly, W. (2011) A World of Becoming. Durham, NC: Duke University Press.

Dunlap, R. and Mertig, A. (1997) Global environmental concern: An anomaly for postmaterialism. Social Science Quarterly 78(1): 24-29.

Esteva, G. and Prakash, M.S. (1998) Grassroots Post-Modernism: Remaking the Soil of Cultures. London: Zed Books.

Foucault, M. (2009) Security, Territory, Population: Lectures at the College de France 1977-78. New York: Picador.

Gabrielson, T. (2011) The normalized toxic body: A site for theorizing an environmental politics. Paper delivered at the Western Political Science Association. Available at SSRN:http://ssm.com/abstract=1766653, accessed 6 June 2015.

Gallagher, J. (2010) Reimagining Detroit: Opportunities for Redefining an American City. Detroit, MI: Wayne State University Press. 
Gallagher, J. (2012a) Detroit residents speak out against project, City Council at Hantz Woodlands hearing, www.freep.com/article/20121210/NEWS01/121210076/Detroit-residents-speak-out-against-projectCity-Council-Hantz-Wodlands-hearing, accessed 16 May 2013.

Gallagher, J. (2012b) Critics say Hantz getting unfair advantage as Detroit council prepares to revisit plan for land sale, www.freep.com/article/20121210/BUSINESS06/312100041/critics-say-hantz-gettingunfair-advantage-as-detroit-council-prepares-to-revisit-plan-for-land-sale, accessed 16 May 2013.

Gottlieb, R. and Joshi, A. (2010) Food Justice. Cambridge, MA: MIT Press.

Guha, R. and Martinez-Alier, J. (eds.) (1997) Varieties of Environmentalism. London: Earthscan.

Hess, D.J. (2009) Localist Movements in a Global Economy: Sustainability, Justice, and Urban Development in the United States. Cambridge, MA: MIT Press.

Hobson, K. (2013) On the making of the environmental citizen. Environmental Politics 22(1): 56-72.

Hopkins, R. (2008) The Transition Handbook: From Oil Dependency to Local Resilience. White River Junction, VT: Chelsea Green.

Hopkins, R. (2011) The Transition Companion: Making Your Community More Resilient in Uncertain Times. White River Junction, VT: Chelsea Green.

Howell, S. (2012) Lessons from Marathon? The Boggs Blog, conversationsthatyouwillneverfinish. wordpress.com/2012/01/16/lessons-from-marathon-by-shea-howell/, accessed 16 May 2013.

Inglehart, R. (1989) Culture Shift in Advanced Industrial Society. Princeton, NJ: Princeton University Press. Inglehart, R. (1997) Modernization and Postmodernization. Princeton, NJ: Princeton University Press.

Inglehart, R. and Welzel, C. (2005) Modernization, Cultural Change, and Democracy: The Human Development Sequence. Cambridge: Cambridge University Press.

Khan, G. (2009) Agency, nature and emergent properties: An interview with Jane Bennett. Contemporary Political Theory 8(1): 90-105.

Kruse, J. and Maegaard, P. (2010) An authentic story of how a local community became self-sufficient in pollution-free energy from wind and created a source of income for the citizens. In: K. Abramsky (ed.) Sparking a Worldwide Energy Revolution: Social Struggles in the Transition to a Post-Petrol World. Oakland, CA: AK Press.

Latour, B. (2011) Love your monsters. In: M. Shellenberger and T. Nordhaus (eds.) Love Your Monsters: Postenvironmentalism and the Anthropocene. Oakland, CA: Breakthrough Institute.

Loftus, A. (2012) Everyday Environmentalism: Creating an Urban Political Ecology. Minneapolis, MN: University of Minnesota Press.

Lovins, A. (1979) Soft Energy Paths. New York: Harper Colophon.

MacGregor, S. (2009) Natural allies, perennial foes? On the trajectories of feminist and green political thought. Contemporary Political Theory 8(3): 317-350.

Maegaard, P. (2010) Denmark: Politically-induced paralysis in wind power's homeland and industrial hub. In: K. Abramsky (ed.) Sparking a Worldwide Energy Revolution: Social Struggles in the Transition to a Post-Petrol World. Oakland, CA: AK Press.

Maniates, M. and Meyer, J. (eds.) (2010) The Environmental Politics of Sacrifice. Cambridge, MA: MIT Press.

Maniates, M.F. (2012) Everyday possibilities. Global Environmental Politics 12(1): 121-5.

Matchar, E. (2011) The new domesticity: Fun, Empowering, or a step back for American women? Washington Post 25 November, http://articles.washingtonpost.com/2011-11-25/opinions/35282982_1_ jam-new-domesticity-domestic-work.

Matchar, E. (2013) Homeward Bound: Why Women are Embracing the New Domesticity. New York: Simon and Shuster.

Oceransky, S. (2010) Fighting the enclosure of wind: Indigenous resistance to the privatization of the wind resource in Southern Mexico. In: K. Abramsky (ed.) Sparking a Worldwide Energy Revolution: Social Struggles in the Transition to a Post-Petrol World. Oakland, CA: AK Press.

Payne, K. (2011) The Hip Girls Guide to Homemaking. New York: Harper Design.

Petrini, C. (2004) Slow Food: The Case for Taste. New York: Columbia University Press.

180 (C) 2016 Macmillan Publishers Ltd. 1470-8914 Contemporary Political Theory Vol. 15, 2, 160-181 
Petrini, C. (2010) Terra Madre: Forging a New Global Network of Sustainable Food Communities. White River Junction, VT: Chelsea Green.

Pollan, M. (2007) Omnivore's Dilemma. New York: Penguin.

Princen, T. (2005) The Logic of Sufficiency. Cambridge, MA: MIT Press.

Read, R. (2008) Transition towns are great - But they won't save us, without help, http://rupertsread. blogspot.com.au/2008/02/transition-towns-are-great-but-they.html, accessed 6 June 2015.

Reel, M. (2014) Saving Detroit, one tree at a time. Bloomberg Businessweek 2 September, http://www .businessweek.com/articles/2014-09-02/detroits-john-hantz-plants-tree-farm-to-fight-urban-decay\#p1.

Schurman, R. and Munro, W. (2010) Fighting for the Future of Food: Activists versus Agribusiness in the Struggle over Biotechnology. Minneapolis, MN: University of Minnesota Press.

Schlosberg, D. (2007) Defining Environmental Justice. Oxford: Oxford University Press.

Shiva, V. (ed.) (2007) Manifestos on the Future of Food and Seed. Boston, MA: South End Press.

Shiva, V. (2008) Soil Not Oil. Boston, MA: South End Press.

Sirriani, C. (2009) Investing in Democracy: Engaging Citizens in Collaborative Governance. Washington DC: Brookings.

Stanton, A. et al (dir) (2008) Wall-E. Burbank, CA: Walt Disney Home Entertainment.

Strom, S. (2012) Has organic been oversized? New York Times 7 July.

Szasz, A. (1994) Ecopopulism: Toxic Waste and the Movement for Environmental Justice. Minneapolis, MN: University of Minnesota Press.

Sze, J. (2006) Boundaries and border wars: DES, technology, and environmental justice. American Quarterly 58(3): 791-814.

Taylor, S. (2013) Vegans, freaks, and animals: Toward a new table fellowship. American Quarterly 65(3): 757-764.

United States Department of Agriculture (USDA) (2013) Farmers markets and local food marketing, http:// www.ams.usda.gov/AMSv1.0/farmersmarkets, accessed 6 June 2015.

Walker, G., Devine-Wright, P., Hunter, S., High, H. and Evans, B. (2010) Trust and community: Exploring the meanings, contexts and dynamics of community renewable energy. Energy Policy 38(6): 2655-2663.

Washick, B., Wingrove, E., Ferguson, K. and Bennett, J. (2015) Politics that matter: Thinking about power and justice with the new materialists. Contemporary Political Theory 14(1): 63-89.

Whitford, D. (2009) Can farming save Detroit? CNN Money 29 December, http://money.cnn.com/2009/12/ 29/news/economy/farming_detroit.fortune/.

Winne, M. (2011) Food Rebels, Guerrilla Gardeners, and Smart-Cookin'Mamas: Fighting Back in an Age of Industrial Agriculture. Boston, MA: Beacon Press.

Whiteside, K. (2013) A representative politics of nature? Bruno Latour on collectives and constitutions. Contemporary Political Theory 12(3): 185-205.

Wolin, S. (2008) Democracy Inc: Managed Democracy and the Specter of Inverted Totalitarianism. Princeton, NJ: Princeton University Press.

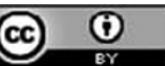

This work is licensed under a Creative Commons Attribution 3.0 Unported License. The images or other third party material in this article are included in the article's Creative Commons license, unless indicated otherwise in the credit line; if the material is not included under the Creative Commons license, users will need to obtain permission from the license holder to reproduce the material. To view a copy of this license, visit http://creativecommons. org/licenses/by/3.0/ 